\title{
Formulation and evaluation of carvedilol microcapsules using Eudragit NE30D and sodium alginate
}

\author{
Trishna Bal ${ }^{1, *}$, Shubhranshu Sengupta ${ }^{2}$, Padala Narasimha Murthy ${ }^{3}$
}

${ }^{1}$ Department of Pharmaceutical Sciences, Birla Institute of Technology, Jharkhand, India, ${ }^{2}$ Department of Horticulture, Birsa Agriculture University, Jharkhand, India, ${ }^{3}$ Royal College of Pharmacy and Health Sciences, Orissa, India

\begin{abstract}
Inclusion complexes of carvedilol(CR) with hydroxyl propyl beta-cyclodextrin (HPBCD) was prepared using co-grinding technique. Then, the inclusion complex was microencapsulated using combinations of Eudragit NE30D (EU) and sodium alginate (SA) utilizing orifice gelation technique. The formulations were analysed by using Scanning electron microscopy (SEM), Fourier Transform Infrared spectroscopy (FTIR), Differential scanning Calorimetry (DSC) and X-ray diffractometer (XRD) and also evaluated for particle size, encapsulation efficiency, production yield, swelling capacity, mucoadhesive properties, zeta potential and drug release. The microcapsules were smooth and showed no visible cracks and extended drug release of $55.2006 \%$ up to 12 hours in phosphate buffer of $\mathrm{pH} 6.8$, showing particle size within the range of $264.5-358.5 \mu \mathrm{m}$, and encapsulation efficiency of $99.337 \pm 0.0100-66.2753 \pm 0.0014 \%$. The in vitro release data of optimized batch of microcapsules were plotted in various kinetic equations to understand the mechanisms and kinetics of drug release, which followed first order kinetics, value of " $n$ " is calculated to be 0.459 and drug release was diffusion controlled. The mice were fed with diet for inducing high blood pressure and the in vivo antihypertensive activity of formulations was carried out administering the optimized formulations and pure drug separately by oral feeding and measured by B.P Monwin IITC Life Science instrument and the results indicated that the bioavailability of carvedilol was increased both in vitro and in vivo with the mucoadhesive polymers showing primary role in retarding the drug release.
\end{abstract}

Uniterms: Carvedilol/microcapsules/evaluation. Carvedilol/microcapsules/formulation. Eudragit NE30D. Orifice Gelation technique.

Prepararam-se complexos de carvedilol (CR) com hidroxipropil beta-ciclodextrina (HPBCD), utilizando a técnica de co-moagem. O complexo de inclusão foi microencapsulado empregando-se associações de Eudragit NE30D (EU) e alginato de sódio (AS), utilizando a técnica de gelificação de orifício. As formulações foram analisadas utilizando-se microscopia eletrônica de varredura (SEM), espectroscopia no infravermelho com Transformada de Fourier, calorimetria diferencial de varredura (DSC) e difratometria de raios X (XDR) e, também, avaliadas por tamanho de partícula, eficiência de encapsulação, rendimento de produção, capacidade de inchamento, propriedades mucoadesivas, potencial zeta e liberação do fármaco. Obtiveram-se microcápsulas lisas e sem fendas visíveis, com liberação prolongada do fármaco de 55,2006\% em 12 horas em tampão fosfato $\mathrm{pH}$ 6,8, com tamanho de partículas na faixa de 264,5-358,5 mm e eficiência de encapsulação de $99,3337 \pm 0,0100-66,2753 \pm 0,0014 \%$. Os dados de liberação in vitro de lote otimizado de microcápsulas foram plotados em várias equações cinéticas para se entender os mecanismos e a cinética de liberação do fármaco, que é de primeira ordem, o valor de "n" foi de 0,459 e a liberação do fármaco foi por difusão controlada. Os camundongos foram alimentados com dieta para induzir pressão sanguínea alta e a atividade anti-hipertensiva in vivo das formulações foi obtida por administração de formulações otimizadas e fármaco puro, separadamente, por via oral e medida pelo equipamento BP Monwin IITC Life Science. Os resultados mostraram que a biodisponibilidade do carvedilol aumentou tanto in vitro quanto in vivo com os polímeros mucoadesivos, mostrando papel principal no retardamento da liberação do fármaco.

Unitermos: Carvedilol/microcápsulas/avaliação. Carvedilol/microcápsulas/formulação. Eudragit NE30D. Técnica de gelificação de orifício.

\footnotetext{
*Correspondence: Trishna Bal. Department of Pharmaceutical Sciences, Birla Institute of Technology, 835215-Mesra-Ranchi-Jharkhand, India. E-mail: twinkisengupta@gmail.com
} 


\section{INTRODUCTION}

The most desirable and convenient method of drug administration is the oral route (Patil et al., 2009). Carvedilol (CR) is a nonselective $\beta$-adrenergic blocking agent with $\alpha_{1}$-blocking activity. It is well absorbed from the gastrointestinal tract but subjected to considerable firstpass metabolism in the liver (Tanwar, Chauhan, Sharma, 2009 ) and its oral bioavailability in humans is only $20 \%$ (Guarve et al., 2009). The drug has a short half-life of 2.2 $\pm 0.3 \mathrm{~h}$. The drug is formulated with a series of polymers to improve the absorption and prolong the half life, thereby preventing degradation in gastric region. Since the drug has low bioavailability due to poor water solubility and slow dissolution rates (Hirlekar, Kadam, 2009) several methods are used to improve the solubility profile of $\mathrm{CR}$, of which complexation with cyclodextrins has been widely used to improve the solubility and dissolution rate of poorly soluble drugs (Wang et al., 2006; Archontaki et al., 2002). Cyclodextrins (CDs) are macrocyclic oligosaccharides with six to eight D-glucose units called $\alpha$-Cyclodextrin, $\beta$-Cyclodextrin and $\gamma$-Cyclodextrin . The most important property of CDs is that they have hydrophobic central cavities capable of forming stable complexes with properly sized drug molecule (Vyas, Saraf, Saraf2008; Shewale et al., 2008; Bhutani et al., 2007). Among the various CDs, hydroxypropyl beta-cyclodextrin (HPBCD) is most successful in improving the dissolution rate (Pitha et al., 1986) of poorly soluble drugs.

Polymeric microparticles are recommended for oral, nasal or pulmonary administration. These systems are able to promote extended release of a bioactive compound and also can protect the drug from degradation and physiological metabolism (Salsa, Veiga, Pina1997). In order to develop microcapsules, several polymers both from natural and synthetic sources can be used (Deasy 1984).

TABLE I - Composition of formulations
The present work is mainly focussed on improving the solubility characteristics of CR by use of CDs, mainly HPBCD by formation of binary systems of CR/ HPBCD in a $1: 1$ ratio $(\mathrm{w} / \mathrm{w}$ ratio) and then formulating this binary system in the form of microcapsules using Orifice Gelation technique, by the use of some mucoadhesive hydrophilic polymers like Sodium alginate and an aqueous dispersion of Eudragit NE30D for oral use. The optimized microcapsules were then evaluated in vitro to determine the drug release and in vivo to determine the efficacy of the formulations.

\section{MATERIAL AND METHODS}

\section{Material}

Carvedilol(CR) was kindly gifted by Glenmark Pharmaceuticals (Mumbai,India), hydroxylpropyl betacyclodextrin (HPBCD) was kindly gifted by Roquette (Lestrem, France), sodium alginate (SA) was purchased from Loba Chemicals(India); Eudragit NE30D (EU) was a gift sample from Evonik Degussa Rohm Pharma (Mumbai, India). All other chemicals used were of analytical reagent grade purity.

\section{Preparation of Microcapsules}

The method used for the preparation of microcapsules adopted was Orifice Gelation technique (Chowdary. Rao, 2003). Binary system of HPBCD/CR was prepared by co-grinding technique (Hirlakar, Kadam 2009) in which mixing of $\mathrm{CR}$ in a ratio of $1: 1(\mathrm{w} / \mathrm{w}$ ratio) with $\mathrm{HPBCD}$ in a glass mortar for 30 minutes was done, and stored in a desiccator. Then this binary system was mixed with SA and EU separately for formulating different batches of microcapsules as stated in Table I. The physical mixtures (PM) (of the CR along with HPBCD, SA and Eudragit NE30D) were analyzed separately for any possible drug-

\begin{tabular}{lccc}
\hline Formulation Code & $\begin{array}{c}\text { Drug (carvedilol): } \\
\text { hydroxypropyl beta- } \\
\text { cyclodextrin (HPBCD) } \\
(\mathrm{mg})\end{array}$ & $\begin{array}{c}\text { sodium alginate(SA) } \\
(\mathrm{mg})\end{array}$ & $\begin{array}{c}\text { Eudragit NE30D(EU) } \\
(\mathrm{mg})\end{array}$ \\
\hline CRSAEU1 & $1: 1$ & 600 & 200 \\
CRSAEU2 & $1: 1$ & 600 & 400 \\
CRSAEU3 & $1: 1$ & 600 & 600 \\
CRSAEU4 & $1: 1$ & 200 & 600 \\
CRSAEU5 & $1: 1$ & 600 & 1050 \\
CRHPSAI & $1: 1$ & 1000 & ----------- \\
\hline
\end{tabular}


excipient interactions. The binary system of HPBCD/ $\mathrm{CR}$ was triturated with SA and then mixed with Eudragit NE30D in a glass mortar pestle and dispersed this mixture in milipore water (obtained from Elix milipore water filter) using magnetic stirrer for $30 \mathrm{~min}$ at $200 \mathrm{rpm}$ and allowed to form uniform slurry named as "CRV". A $3 \% \mathrm{w} / \mathrm{v}$ calcium chloride solution was prepared and filtered separately and to this solution, the slurry "CRV" was added dropwise through a $10 \mathrm{~mL}$ syringe (Dispovan) having needle of size no.26G . The microcapsules formed were allowed to remain in the calcium chloride solution for $30 \mathrm{~min}$ to complete the curing reaction. The formed microcapsules were filtered and washed with millipore water to remove any traces of calcium chloride from the microcapsule surfaces and dried the microcapsules in open air and kept in a desiccator.

\section{Evaluation of microcapsules}

\section{Determination of Yield of Production}

The production yields (Ranjha, Khan, Nazeem, 2010) of microspheres of various batches were calculated using the weight of finally dried microspheres with respect to the initial total quantity of the drug and polymer used for preparation. Percent production yields were calculated as per the formula below:

$$
\text { Production yield }=\frac{\text { Practical mass (microspheres) }}{\text { Theoretical mass }(\text { polymer }+ \text { drug })} \times 100
$$

\section{Determination percentage encapsulation efficiency}

Percentage encapsulation efficiency is the percentage of drug encapsulated in the microcapsules related to the initial quantity of the drug used in the formulation. $100 \mathrm{mg}$ of microcapsules were taken and crushed in a glass mortar-pestle. In a $100 \mathrm{~mL}$ volumetric flask, the grounded microcapsule powder was mixed with methanol to make up the volume up to $100 \mathrm{~mL}$ and placed the whole system in a sonicator for $30 \mathrm{~min}$ to get the maximum extraction of CR in the solvent. The sample so obtained were filtered to obtain clear solution and assayed for the drug content spectrophotometrically at $242 \mathrm{~nm}$. Percent encapsulation efficiency (Ranjha, Khan, Nazeem, 2010) was determined by using the formula below.

Percentage Encapsulation efficiency $=\frac{\text { Actual Drug Content }(\mathrm{mg})}{\text { Practical drug Content }(\mathrm{mg})} \times 100$

\section{- $\quad$ Particle Size}

The Particle size of the dried microcapsules was measured using a stage micrometer scale by optical microscopy method. This study was done in triplicate. 100 nos. of dry microcapsules were placed on a clean glass slide and a few drops of liquid paraffin was added and covered with a glass slide and observed under a compound microscope using stage and ocular micrometer (Dhaliwal et al., 2008; Patil et al., 2009).

\section{- Determination of bulk density}

The bulk density of the formulations was determined by using the following formula (Ranjha, Khan, Nazeem, 2010). This study was done in triplicate.

$$
\text { Bulk density }=\frac{\text { Sample Weight }}{\text { Sample Volume }}
$$

\section{- Determination of Tapped density}

Tapped Density is used to investigate packing properties of microcapsules into capsules. The Tapped density was measured by employing the conventional tapping method using a $10 \mathrm{ml}$ measuring cylinder and the number of tapings was 100 as sufficient to bring a plateau condition. This study was done in triplicate. Tapped density was calculated by using the following formula (Ranjha, Khan, Nazeem, 2010):

$$
\begin{gathered}
\text { Tapped density }=\frac{\text { Weight of the microspheres }}{\text { Volume of microcapsules }} \\
\text { after } 100 \text { tappings }
\end{gathered}
$$

- Determination of Carr's consolidation Index

It is indirect measurement of bulk density, size and shape, surface area, moisture content and cohesiveness of materials since all of them can influence the consolidation index. It is also called as Compressibility index (Ci). This study was done in triplicate. It is denoted by $\boldsymbol{C} \boldsymbol{i}$ and is calculated using the formula below (Ranjha, Khan, Nazeem, 2010):

$$
\mathrm{Ci}=\frac{\text { Tapped density }- \text { Bulk density }}{\text { Bulk density }}
$$

A Carr's index less than $15 \%$ is referred to as very good flow, $16-26 \%$ is good, $27-35 \%$ is fairly good and $\wp 35 \%$ are considered as poor (Carr, 1965).

\section{- Determination of Hausner's ratio}

It is another parameter for measuring flowability of the microcapsules. This study was done in triplicate. It is calculated using the following formula (Ranjha, Khan, Nazeem, 2010):

$$
\text { Hausner's ratio }=\frac{\text { Volume before tapping }}{\text { Volume after tapping }}
$$

\section{- Determination of Angle of repose}

Angle of repose $\left(\theta=\tan ^{-1} \mathrm{~h} / \mathrm{r}\right)$ of the microcapsules was determined by passing the microcapsules through 
the glass funnel on a horizontal surface (Ranjha, Khan, Nazeem, 2010). This study was done in triplicate. The height ( $h$ ) of the heap formed was measured and the radius (r) of the cone base was also observed and calculated.

- $\quad$ Percentage of swelling of Microcapsules

Swelling rate of the microcapsules was measured as a function of water uptake. The formulations were placed in phosphate buffer of $\mathrm{pH} 6.8$ at room temperature for a time period of 10 hours. At different time intervals, the microcapsules were taken out and very gently pressed with a tissue paper to remove the excess liquid and then weighed. These studies were done in triplicate. The percentage swelling of the microcapsules was determined by using the following formula as below (Patil Sanjay, Sawant Krutika , 2009):

$$
\% \text { Water uptake }=-100 \times \frac{\begin{array}{c}
\text { Weight of wet } \\
\text { microcapsules }
\end{array}-\begin{array}{c}
\text { Weight of dry } \\
\text { microcapsules }
\end{array}}{\text { Weight of dry microcapsules }}
$$

- Mucoadhesion properties of the microcapsule

Bioadhesive strength of the microcapsules was measured on a modified physical balance using the method described by Gupta, Garga and Khar(1992). Carbopol 934P which was taken as standard to compare the mucoadhesivity of microcapsules. The microcapsules were sandwiched between two mucosal surfaces of rat intestine. The intestine were placed on two oppositely placed platforms of two slides, one hanged to the left pan of balance and other placed on a water bath at the base. Then weights were placed to the right pan of the balance in ascending order starting from lower weights and after each addition of weights, allowing to stand for $1 \mathrm{~min}$, and then added the next weight and this process was continued till the two mucosal surfaces detached from one another on the left side of pan and thus the detachment force required to separate two glass slides was measured. This study was done in triplicate.

\section{In vitro Drug release of microcapsules}

$900 \mathrm{~mL}$ of phosphate buffer of pH6.8 (Hirlekar, Kadam, 2009) was taken as dissolution medium for in vitro drug release in USP Type-I dissolution apparatus. $100 \mathrm{mg}$ of the microcapsules were taken and filled in a hard gelatin capsule and placed in the basket and started the dissolution at $75 \mathrm{rpm}$ and continued the study for a period of 13 hours. $5 \mathrm{ml}$ of sample was withdrawn after every $0.5,1,2,3,4,5,6,7,8,9,10,11,12,13$ hours and analyzed spectrophotometrically at $241 \mathrm{~nm}$ and calculated the cumulative drug release and calculated the drug release kinetics. This study was done in triplicate. The statistical ANOVA analysis of the in vitro release studies is also plotted.

Data obtained from in vitro release studies were fitted to various kinetic equations to find out the mechanisms of the drug release. The kinetic models used were Zero order equation, first order Equation, Higuchi equation, Hixson Crowell Equation, Peppas-Korsmeyer Equation.

\section{Phyisicochemical evaluations of microcapsules}

- $\quad$ FTIR spectroscopy (Ranjha, Khan, Nazeem, 2010)

Binary System (HPBCD/CR)-Polymers interactions were studied by FTIR spectroscopy (FTIT Shimadzu 8400 S). Also the spectra for pure drug and drug loaded microcapsules were recorded. Samples were prepared in $\mathrm{KBr}$ disks (2 mg sample in $200 \mathrm{mg}$ of $\mathrm{KBr}$ ). The scanning was $400-4000 \mathrm{~cm}^{-1}$ and the resolution was $2 \mathrm{~cm}^{-1}$.

\section{- $\quad \mathrm{X}$-ray powder diffractometry}

This technique was carried out to investigate the effect of polymers and complexing agent HPBCD on the characteristics of the drug after formulation. Powdered samples of pure drug, polymers, HPBCD and microcapsules were irradiated with monochromatized $\mathrm{X}$-rays $(\mathrm{Cu}-\mathrm{k} \alpha)$ of $30 \mathrm{kV}$ and $15 \mathrm{~mA}$ current in a Rigaku analytical XRD (Model Miniflex, Japan).The scanning rate employed was $0.2^{0} \mathrm{~min}^{-1}$ of $2 \theta$. The $\mathrm{X}$-ray powder diffractometry (X-RD) patterns of the dug and drug loaded microcapsules were recorded (Ranjha, Khan, Nazeem, 2010).

- DCS studies of the microcapsule (Ranjha, Khan, Nazeem, 2010;

$5 \mathrm{mg}$ weight of samples(Pure drug, Polymers, optimized microcapsule) were taken to carry out tests in DSC using Aluminium sample pans at a scanning speed of $10{ }^{\circ} \mathrm{C}$ per min form $10{ }^{\circ} \mathrm{C}-200^{\circ} \mathrm{C}$ to detect any interaction between drug and polymers.

\section{Morphological studies of microcapsules}

The optimized batch of microcapsules used for determination of surface morphology were coated by gold sputtering technique and observed using the Scanning electron microscope (Ranjha, Khan, Nazeem, 2010) (Model Jeol Japan; JSM-6390LV).

\section{Determination of zeta potential of microcapsules}

The optimized batch of formulation was dispersed in phosphate buffer of $\mathrm{pH} 6.8$ and the surface charge (zeta potential) was measured by laser doppler anemometry using a Zetamaster (Malvern, UK) (Patil Sanjay, Sawant 
Krutika, 2009). Also the zeta potential of the individual polymers and the drug were measured for a comparative study.

In vivo animal studies

- Animals

Male swiss albino mice weighing from 100-120 g were housed in a temperature and light controlled room $\left(23 \pm 2{ }^{\circ} \mathrm{C} ; 12\right.$ hours light/dark cycle), with free access to water and food. All the procedures are in agreement to the Institutional animal ethical committee, BIT, Mesra, Ranchi (vide letter No.CPCSEA approval no: 621/02/ac/ CPCSEA).

\section{Experimental protocol}

Eighteen male mice of eight weeks old were randomly selected and divided in three groups of 6 animals each of weight of 20-50 g. Group 1 received pure carvedilol (CR); Group 2 received optimized formulation CRSAEU5 $\{$ at $10 \mathrm{mg} / \mathrm{kg}$ (Schaefer et al., 1998)\}; Group 3 was taken as the control (without any drug or formulations, only provided with water and normal food). For all the three groups initially, before any treatment, the mice were acclamatized for 3 days in the warming chamber of the

TABLE II - Diet Composition for mice for inducing Hypertension (Qianli et al., 2004)

\begin{tabular}{lc}
\hline Ingredients & Amount $(\mathrm{mg})$ \\
\hline Protein & 14 \\
Fat & 20 \\
Fiber & 0.5 \\
Carbohydrate & 10 \\
Mineral Mix & 0.35 \\
Vitamin Mix & 0.1 \\
$\mathrm{NaCl}$ & 8 \\
\hline
\end{tabular}

B.P Monwin IITC Life Science instrument. On the 4rth day, blood pressure was measured by noninvasive tail cuff method using B.P Monwin IITC Inc. Life Science instrument. Then for one week the animals of Group1 \&2 were given diet as given in Table II for inducing Hypertension (Qianli et al., 2004). After one week, the B.P was again measured for all the three groups to observe the increase in B.P and after confirming that there is induction of hypertension, treatment was started with pure drug CR and optimized microcapsules batch CRSAEU5 in two different groups respectively.

\section{Statistical evaluations for In-vivo studies of optimized carvedilol microcapsules in mice}

The data of statistical ANOVA one way analysis was calculated in Graph Pad software in mice for optimized formulations of carvedilol CRSAEU5 is presented in Figure 7 and Figure 8. The IITC life sciences Blood pressure (B.P) measuring instrument for mice which was utilized during the experiment is presented in Figure 9.

\section{RESULTS AND DISCUSSION}

\section{Effect of technique on the formation of microcapsules}

Mucoadhesive carvedilol microcapsules prepared by orifice Gelation technique using a mixure of natural polymers and aqueous dispersion of ethylcellulose i.e. Eudragit NE30D were found to be free flowing and almost spherical in shape. The preparation method used was advantageous for entrapment of water-insoluble drugs. Moreover by formation of binary system of HPBCD/ $\mathrm{CR}$, solubility parameter of drug $\mathrm{CR}$ was increased. The production of microcapsules varied with different ratios of polymers. The results are shown in Table III. The high yield of the microcapsules may be due to the entire mass

TABLE III - Micromeritic properties along with encapsulation efficiency, \%yield and assessment of mucoadhesivity of formulations

\begin{tabular}{|c|c|c|c|c|c|c|c|c|c|}
\hline S1. No. & $\begin{array}{l}\text { Formulation } \\
\text { Code }\end{array}$ & $\begin{array}{c}\% \\
\text { Encapsulation } \\
\text { efficiency } \\
(\% \text { E.E) }\end{array}$ & $\%$ Yield & $\begin{array}{c}\text { Particle Size } \\
\qquad(\mu \mathrm{m})\end{array}$ & $\begin{array}{c}\text { Mucoadhesivity } \\
\text { [Detachment } \\
\text { Strength } \\
\left.\left(\mathrm{N} / \mathrm{Cm}^{2}\right)\right]\end{array}$ & $\begin{array}{c}\text { Assessment } \\
\text { of Duration of } \\
\text { Mucoadhesion } \\
\text { in (min) }\end{array}$ & $\%$ C.I & $\begin{array}{l}\text { Hausner's } \\
\text { Ratio }\end{array}$ & $\begin{array}{l}\text { Angle of } \\
\text { Repose }\end{array}$ \\
\hline 1 & CRSAEU1 & $66.2753 \pm 0.0014$ & 91.1529 & $317.5 \pm 15.08$ & 0.021909 & $1.4 \pm 0.100$ & $9.1 \pm 0.152$ & $1.091 \pm 0.009$ & $13.2 \pm 0.4612$ \\
\hline 2 & CRSAEU2 & $78.759 \pm 0.001$ & 88.6315 & $335.0 \pm 11.527$ & 0.021582 & $1.5 \pm 0.05773$ & $9.1 \pm 0.152$ & $1.091 \pm 0.009$ & $12.19 \pm 0.5411$ \\
\hline 3 & CRSAEU3 & $82.598 \pm 0.0005$ & 81.6 & $358.5 \pm 11.527$ & 0.021909 & $1.4 \pm 0.100$ & $15.96 \pm 0.647$ & $1.16 \pm 0.0055$ & $12.103 \pm 0.3874$ \\
\hline 5 & CRSAEU5 & $99.337 \pm 0.0100$ & 91.636 & $\mathbf{2 6 4 . 5} \pm 7.527$ & 0.023217 & $1.6 \pm 0.100$ & $\mathbf{8 . 3} \pm 0.1301$ & $\mathbf{1 . 0 8 3} \pm 0.0012$ & $\mathbf{1 1 . 2 4} \pm 0.4652$ \\
\hline 6 & CRHPSAI & $65.84 \pm 0.080$ & 85.71 & $358.5 \pm 11.527$ & 0.022236 & $1.33 \pm 0.3055$ & $14.3 \pm 0.7419$ & $1.14 \pm 0.0100$ & $12.0115 \pm 0.245$ \\
\hline 7 & Carbopol 934P & ------------ & ------ & --------- & 0.0256041 & $1.5 \pm 0.100$ & ------ & ------------ & --------- \\
\hline
\end{tabular}


TABLE IV - Bulk and tapped density of formulations (Mean \pm S.D)

\begin{tabular}{lcccccc}
\hline Sl.No. & $\begin{array}{c}\text { Formulation } \\
\text { Code }\end{array}$ & $\begin{array}{c}\text { Weight taken in } \\
(\mathrm{gm})\end{array}$ & $\begin{array}{c}\text { Bulk Volume } \\
(\mathrm{mL})\end{array}$ & $\begin{array}{c}\text { Tapped Volume } \\
(\mathrm{mL})\end{array}$ & $\begin{array}{c}\text { Bulk Density } \mathrm{B}_{\mathrm{D}} \\
(\mathrm{g} / \mathrm{mL})\end{array}$ & $\begin{array}{c}\text { Tapped Density } \mathrm{T}_{\mathrm{D}} \\
(\mathrm{g} / \mathrm{mL})\end{array}$ \\
\hline 1 & CRSAEU1 & 1.0 & $1.2 \pm 0.005$ & $1.1 \pm 0.005$ & $0.909 \pm 0.005$ & $1.2 \pm 0.005$ \\
2 & CRSAEU2 & 1.0 & $1.2 \pm 0.005$ & $1.1 \pm 0.005$ & $0.909 \pm 0.005$ & $1.2 \pm 0.005$ \\
3 & CRSAEU3 & 1.0 & $0.694 \pm 0.002$ & $0.598 \pm 0.005$ & $1.666 \pm 0.002$ & $0.7 \pm 0.005$ \\
4 & CRSAEU4 & 1.0 & $0.9 \pm 0.01$ & $1.0 \pm 0.011$ & $1.25 \pm 0.01$ & $1.0 \pm 0.011$ \\
$\mathbf{5}$ & CRSAEU5 & $\mathbf{1 . 0}$ & $\mathbf{1 . 3} \pm 0.005$ & $\mathbf{0 . 7 6 9} \pm 0.005$ & $\mathbf{0 . 8 3 3} \pm 0.005$ & $\mathbf{1 . 3} \pm 0.005$ \\
6. & CRHPSAI & 1.0 & $0.79 \pm 0.006$ & $1.7 \pm 0.008$ & $0.555 \pm 0.006$ & $0.588 \pm 0.008$ \\
\hline
\end{tabular}

of the polymer available for gelation by the crosslinking agent. These studies were done in triplicate.

As the drug is water insoluble, so most of the drug got entrapped in the polymer matrix resulting higher drug content and high percentage encapsulation efficiency. Moreover as the amount of both the polymers increased, the entrapment efficiency also increased.

\section{Micromeritic properties}

As observed in Table III, the particle size of the different batches of microcapsules ranged from 264.5$358.5 \mu \mathrm{m}$ as determined by optical microscopy method. The formulation CRSAEU5 showed the least particle size of $264.5 \mu \mathrm{m} \pm 1.527$ among the other formulations, showing that is a better formulation. Moreover as seen from Table III, CRSAEU5 is the superior among all the other formulations as the hausner's ratio, \% compressibility index and angle of repose is smallest among all the other formulations (Ranjha, Khan, Nazeem, 2010). The bulk and tapped density data are given in Table IV.

\section{Swelling studies}

The results of swelling studies of all the formulations as compared to CRHPSAI as shown in Figure 1, indicates that with the increase in polymer concentration, the water

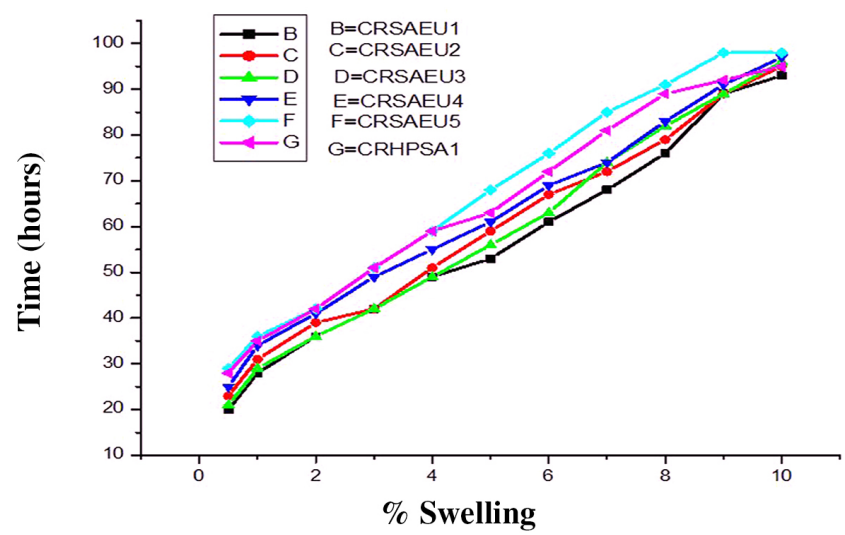

FIGURE 1 - Comparative $\%$ swelling studies of all formulations. absorption capacity of the formulations also increase. These studies were done in triplicate. These studies are in confirmation with earlier studies (Xiudong et al., 2004). The statistical studies of the optimized formulation CRSAEU5 is shown in Figure 2.

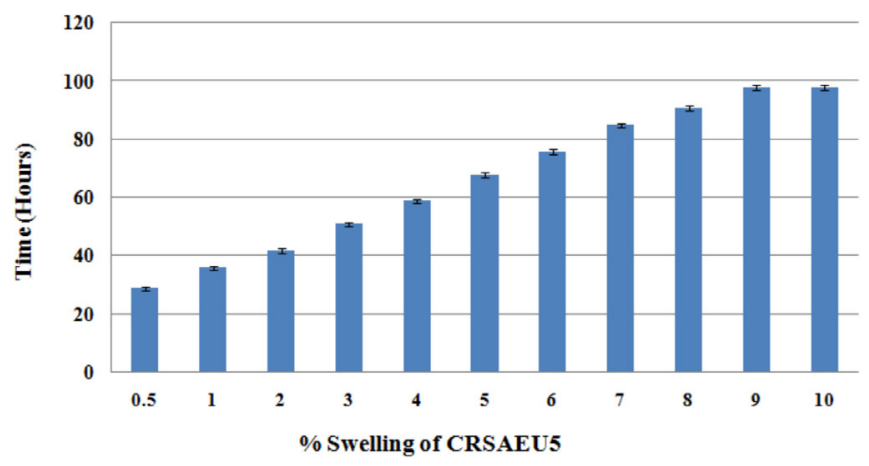

FIGURE 2 - \% swelling studies of formulation CRSAEU5 $\pm \mathrm{S}$.D, $\mathrm{n}=3$.

\section{Mucoadhesion studies}

As observed from the Table III, CRSAEU5 shows the highest mucoadhesive property. With the increase in both polymer concentrations, there is an increase in mucoadhesion. Also this is supported by results of assessment of duration of mucoadhesion as cited in Table III.As shown in Figure 3, microcapsules adhesioned to the rat intestine of $3 \mathrm{~cm}^{2}$ area, where length is $3 \mathrm{~cm}$ and breadth is $1 \mathrm{~cm}$.

\section{In vitro release studies}

The in-vitro release studies were carried out in $\mathrm{pH}$ 6.8 phosphate buffer. It was observed that at alkaline $\mathrm{pH}$, greater stress was caused to the polymers thereby causing release of drugs. The microcapsules swelled excessively followed by erosion in the buffered alkaline medium. Eudragit NE30D shows the gelling property in alkaline medium which is considered beneficial for sustaining drug release from the microcapsules. The microcapsules 
showed sustained release for a period of 13 hours due to the hindered diffusion of the drug from the gel matrix of Sodium alginate and Eudragit NE30D formed in situ (Sharma, Sarangi, Pradhan2009) and thereby causing retarded drug release. The release of drugs was retarded with the increase in the polymer ratio. From the Figure 3 , it is clearly visible that formulation CRSAEU5 has the highest property of retarding the drug release. The results were compared with Formulation CRHPSAI (devoid of Eudragit NE30D) and it is seen that drug release from CRHPSAI is $98 \%$ within 7 hours. Thus Eudragit NE30D is highly effective in retarding the drug release. This study was done in triplicate.

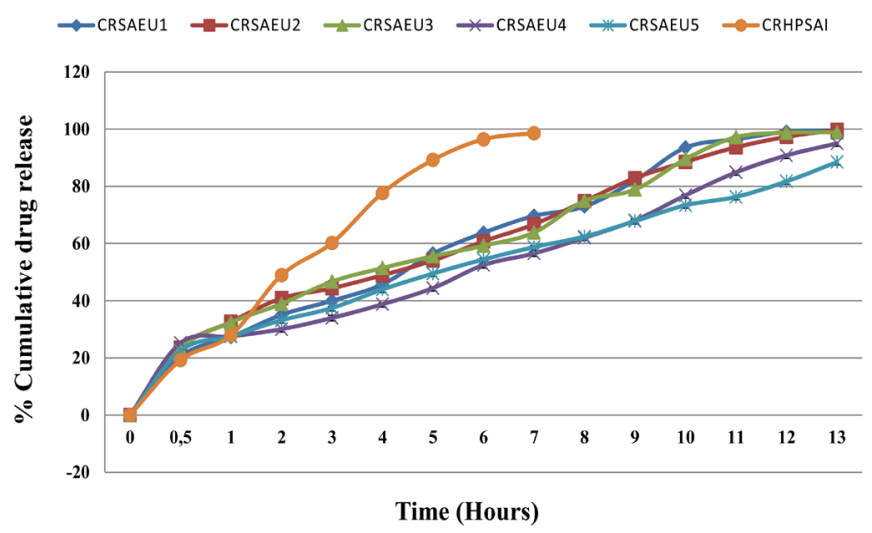

FIGURE 3 - Comparative Drug Release Profile of microcapsules at pH 6.8; CRSAEU4(filled (Diamond,Ser.1),CRSAEU1(Filled Square,Ser.2), CRSAEU5(Filled triangle, Series 3), CRSAEU2 (Cross, Ser.4), CRSAEU3(Star,Ser.5), CRHPSAI(Filled Circle,Ser.6), Mean \% cumulative drug release \pm S.D, $n=3$

\section{Kinetics of drug release}

Inorder to understand the mechanism and kinetics of invitro drug release, the data were analyzed with various kinetic equations like Zero order(\% Cumulative drug release Vs time in hours), First order plot(log of Cumulative \% drug unreleased Vs Time), Higuchi model $(\%$ Cumulative Drug released Vs Square root of time) and Korsmeyer-Peppas Plot (log\% Cumulative drug released Vs log of time). Coefficient of Correlation values were calculated for the linear curves obtained by regression analysis of the above plots.

As observed from Figure 3, it is clear that formulation CRSAEU5 retards the drug release for a longer period of time than in comparison to other formulations, thereby controlling the drug release. From Table V, it is clear that, CRSAEU5 follows first order release mechanism and value of " $n$ " is 0.459 which indicates that the mechanism of the drug to diffusion controlled (Sharma, Sarangi, Pradhan 2009; Mukherjee et al., 2005).

\section{Surface topography}

After considering all the parameters of evaluation formulation CRSAEU5 is considered as most efficient. Surface morphologies of the formulation CRSAEU5 as confirmed by SEM studies shows that there are no cracks or crevices present on the surface as shown in Figure 4.

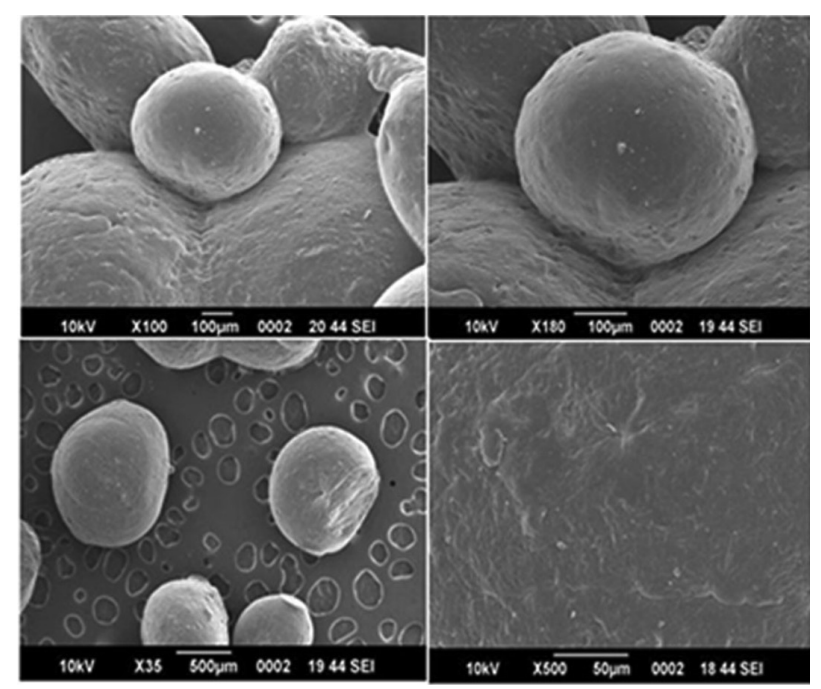

FIGURE 4 - Scanning electron microscopy of CRSAEU5.

TABLE V - Release kinetics of carvedilol from microcapsules

\begin{tabular}{lccccccccccc}
\hline \multirow{2}{*}{ Sl. No. } & $\begin{array}{c}\text { Formulation } \\
\text { Code }\end{array}$ & \multicolumn{2}{c}{$\begin{array}{c}\text { Zero order } \\
\text { Kinetics }\end{array}$} & \multicolumn{2}{c}{$\begin{array}{c}\text { First order } \\
\text { Kinetics }\end{array}$} & \multicolumn{2}{c}{$\begin{array}{c}\text { Higuchi } \\
\text { Kinetics }\end{array}$} & \multicolumn{2}{c}{$\begin{array}{c}\text { Hixson Crowell } \\
\text { Kinetics }\end{array}$} & \multicolumn{2}{c}{$\begin{array}{c}\text { Korsmeyer-Peppas } \\
\text { Kinetics }\end{array}$} \\
\cline { 3 - 13 } & & $\boldsymbol{R}^{2}$ & $\boldsymbol{k}_{\boldsymbol{n}}$ & $\boldsymbol{R}^{2}$ & $\boldsymbol{k}_{\boldsymbol{l}}$ & $\boldsymbol{R}^{2}$ & $\boldsymbol{k}_{\boldsymbol{H}}$ & $\boldsymbol{R}^{2}$ & $\boldsymbol{k}_{\boldsymbol{H C}}$ & $\boldsymbol{R}^{2}$ & $\boldsymbol{n}$ \\
\hline 1 & CRSAEU1 & 0.964 & 7.131 & 0.825 & -0.153 & 0.980 & 28.69 & 0.945 & -0.278 & 0.968 & 0.423 \\
2 & CRSAEU2 & 0.951 & 6.654 & 0.763 & -0.138 & 0.980 & 26.94 & 0.934 & -0.253 & 0.966 & 0.443 \\
3 & CRSAEU3 & 0.948 & 6.678 & 0.827 & -0.135 & 0.976 & 27.02 & 0.926 & -0.256 & 0.968 & 0.446 \\
4 & CRSAEU4 & 0.967 & 6.233 & 0.861 & -0.079 & 0.943 & 24.56 & 0.931 & -0.188 & 0.883 & 0.436 \\
$\mathbf{5}$ & CRSAEU5 & $\mathbf{0 . 9 6 3}$ & $\mathbf{3 . 5 2 0}$ & $\mathbf{0 . 9 6 7}$ & $\mathbf{- 0 . 0 2 2}$ & $\mathbf{0 . 9 6 6}$ & $\mathbf{1 4 . 0 6}$ & $\mathbf{0 . 9 6 3}$ & $\mathbf{- 0 . 0 7 1}$ & $\mathbf{0 . 9 4 5}$ & $\mathbf{0 . 4 5 9}$ \\
6 & CRHPSAI & 0.948 & 14.01 & 0.938 & -0.250 & 0.984 & 40.71 & 0.991 & -0.501 & 0.993 & 0.654 \\
\hline
\end{tabular}




\section{Zeta potential measurement}

The Zeta potential value of CRSAEU5 as seen from Table VI is found to be more towards the positive side than in comparison to the pure drug. The increase in zeta potential may be due to the contribution of HPBCD and Eudragit NE30D. This increase in zeta potential of the formulation also contributes to the increase in mucoadhesive property of the formulation as seen in Table III. This result is in confirmation with earlier studies (Dhawan, Singla, Sinha, 2004).

TABLE VI - Zeta potential of optimized formulation, polymers, pure drug

\begin{tabular}{lcc}
\hline Sl.No. & $\begin{array}{c}\text { Formulation/Polymer/ } \\
\text { Drug }\end{array}$ & $\begin{array}{c}\text { Zeta potential } \\
(\mathrm{mV})\end{array}$ \\
\hline 1 & CRSAEU5 & -20.2 \\
2 & sodium Alginate & -67.3 \\
3 & Eudragit NE30D & -17.2 \\
4 & HPBCD & -19.4 \\
5 & carvedilol & -28.2 \\
\hline
\end{tabular}

\section{FTIR analysis}

As observed in Figure 5, FTIR studies indicated weak interactions of carvedilol with HPBCD at 1:1 ratio prepared in the form of microcapsules with different polymers as shown in Figure 7. In carvedilol spectra, absorption peaks were observed at $3349.7701 \mathrm{~cm}^{-1}$, $2933.55621 \mathrm{~cm}^{-1}$ due to hydroxyl and amine stretching respectively. Other peaks were at $1233.5979 \mathrm{~cm}^{-1}$ due to $\mathrm{C}$-O group (epoxides), $1094.86001 \mathrm{~cm}^{-1}$ due

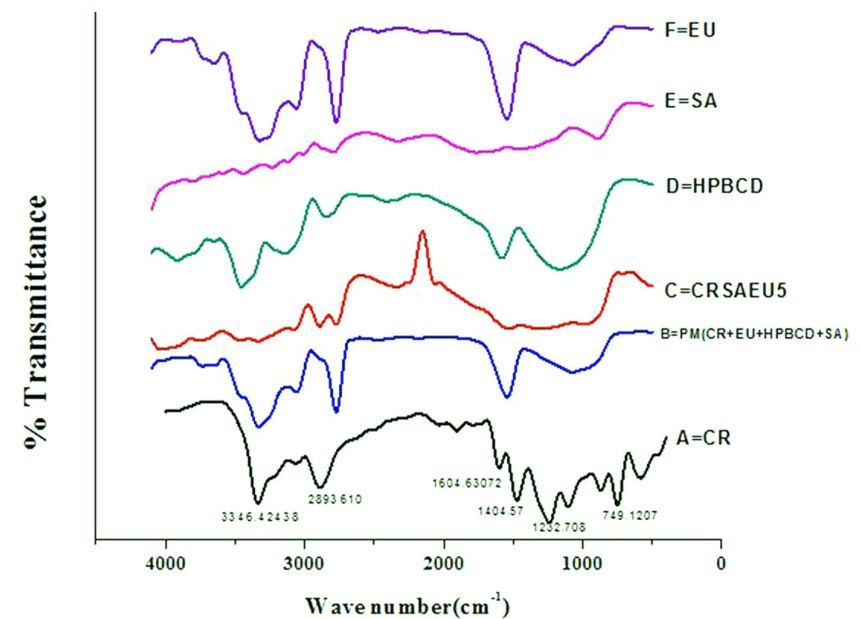

FIGURE 5 - FTIR spectra of CRSAEU5, physical mixture (PM), HPBCD, carvedilol, sodium alginate, Eudragit NE30D. to aryl alkyl ethers and alkyl ether C-O stretching respectively. Whereas in the $\mathrm{PM}$, there is an exhibition at $3339.7409 \mathrm{~cm}^{-1}, 2913.4977 \mathrm{~cm}^{-1}$ due to hydroxyl and amine stretching respectively which matches with pure drug. Also there is an exhibition at $1273.715 \mathrm{~cm}^{-1}$, $1064.77225 \mathrm{~cm}^{-1}$ which matches with that of pure drug showing still the presence of aryl alkyl ethers and alkyl ether C-O stretching respectively. In case of Formulation CRSAEU5, there is appearance of broad wave number of $3261.17844 \mathrm{~cm}^{-1}$ indicating the presence of hydroxyl stretching, and there is very less intensity of presence of $1064.77225 \mathrm{~cm}^{-1}$ indicating the entrapment of carbazol moiety into host cavity during inclusion complex. The results are in confirmation with Hirlekar and Kadam (2009).

\section{XRD analysis}

The XRD patterns of pure Carvedilol (CR), physical mixture (PM), pure HPBCD, formulation CRSAEU5 are illustrated in Figure 6 and Figure 7. The diffraction pattern of the physical mixture is simply superimposition or summation of the drug and HPBCD with similar sharp peaks.Nevertheless some changes like peak locations,reduction in peak intensities were observed in the diffractograms of physical Mixture(Table IX) indicating the possibility of some kind of interactions between CR and HPBCD. The formulation also presented a diffraction pattern quite similar to that of physical mixture but with much lower intensities.Also there was disapperance of diffraction peaks of drug in the formulation CRSAEU5. Rajashree Hiralkar et al. found the similar results for CR-M $\beta C D$ complexes (Hirlekar, Kadam 2009). These phenomena confirmed that an inclusion complex between

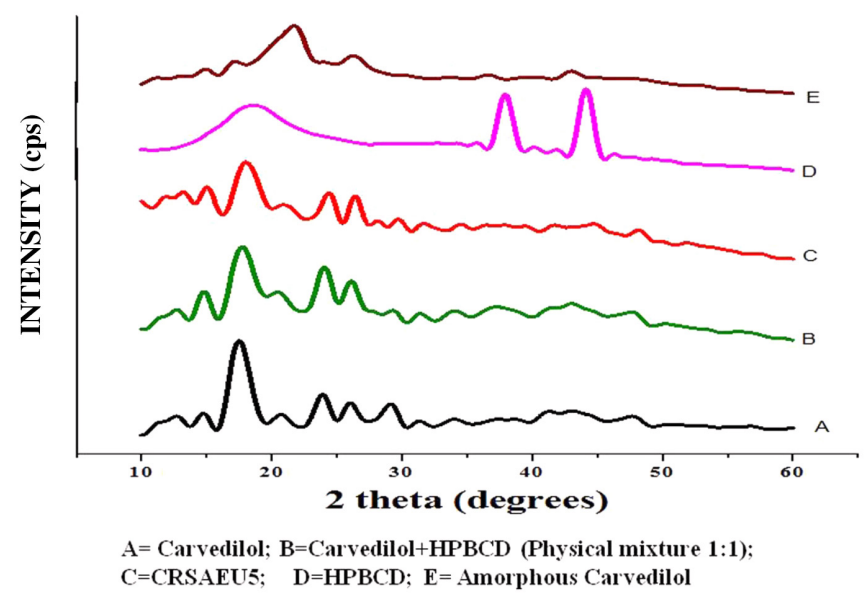

FIGURE 6 - X-ray diffractograms of CRSAEU5, pure carvedilol, pure HPBCD and amorphous carvedilol. 
TABLE VII - Peak intensities of CR in XRD patterns of CR-HPBCD systems

\begin{tabular}{lcccccc}
\hline \multirow{2}{*}{ S1.No. } & \multirow{2}{*}{$2 \theta$} & CR & HPBCD & \multicolumn{2}{c}{ CR:HPBCD } & \multirow{2}{*}{ Amorphous CR } \\
\cline { 5 - 6 } 1 & & & & PM & CRSAD4 & \\
2 & 11.47 & 102 & ---- & 36 & 24 & 24 \\
3 & 12.82 & 158 & ---- & 78 & 23 & 15 \\
4 & 14.62 & 130 & ----- & 118 & 44 & 35 \\
5 & 17.32 & 630 & 15 & 223 & 92 & 80 \\
6 & 24.100 & 186 & 10 & 158 & 47 & 16 \\
7 & 26.110 & 152 & ---- & 124 & 39 & 44 \\
\hline
\end{tabular}

the CR and HPBCD.The results in Table VII,showed the crystalline characteristics of the drug $\mathrm{CR}$ disapperared when complexed with HPBCD as seen in CRSAEU5. Moreover the peak intensities was found to be reduced in amorphous CR.

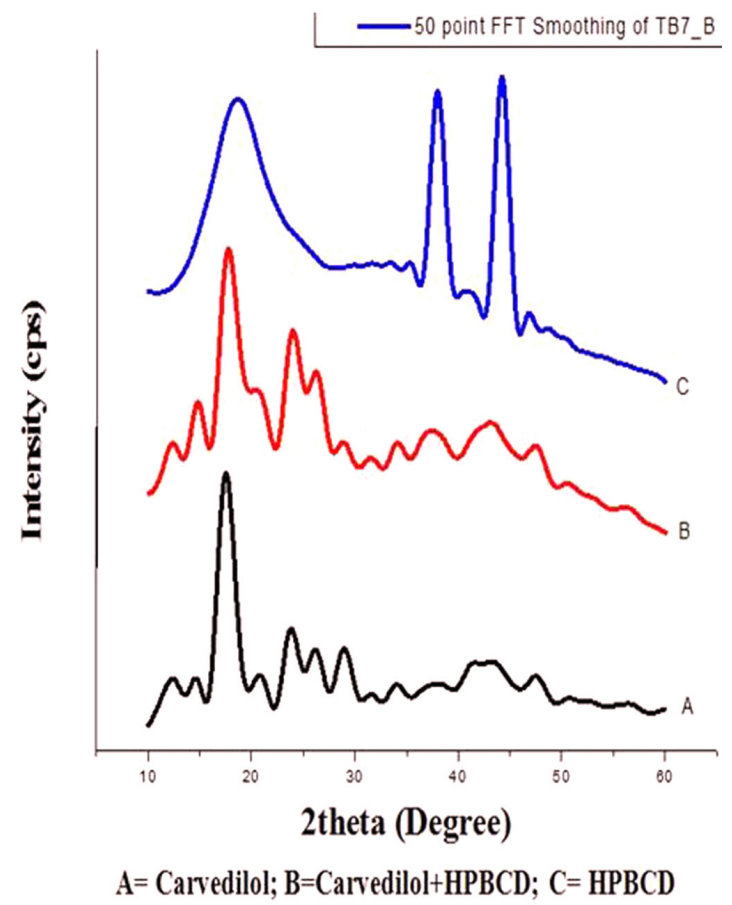

FIGURE 7 - X-ray diffractograms of Physical mixtures carvedilol with HPBCD in a ratio of 1:1.

\section{DSC analysis}

DSC studies can be used for the recognition of inclusion complexes (Hirlekar, Kadam, 2009). When the guest molecules were embedded in cyclodextrin cavity, their melting point, boiling or sublimation points generally shifted to a different temperature (Magnusdottir,
Masson, Loftsson, 2002). The thermograms of CR along with Physical mixtures, formulation CRSAEU5 and Pure HPBCD are shown in Figure 8. The thermogram of CR was typical of a highly crystalline compound characterized by a sharp endothermic peak at $118^{\circ} \mathrm{C}$ which corresponded to its melting point too (Miro et al., 2006). The DSC thermogram of HPBCD showed a broad endotherm which attained a maximum around $100{ }^{\circ} \mathrm{C}$ due to release of water molecules. The PM also did not retain the drug endothermic peak and showed a broad peak at $100.91{ }^{\circ} \mathrm{C}$ which showed that the complex of the drug and HPBCD in solution state loses the crystalline properties of the drug and thus converts the drug amorphous. Similarly, formulation CRSAEU5 showed broad endothermic peak at $95-105^{\circ} \mathrm{C}$. This may be due to the shift of characteristics peak of $\mathrm{CR}$, which was observed at $117{ }^{\circ} \mathrm{C}$, thereby indicating weak interaction of drug CR with HPBCD. This indicates that there is formation of an amorphous drug, thereby indicating the formation of Inclusion Complex of $\mathrm{CR}$ in HPBCD.

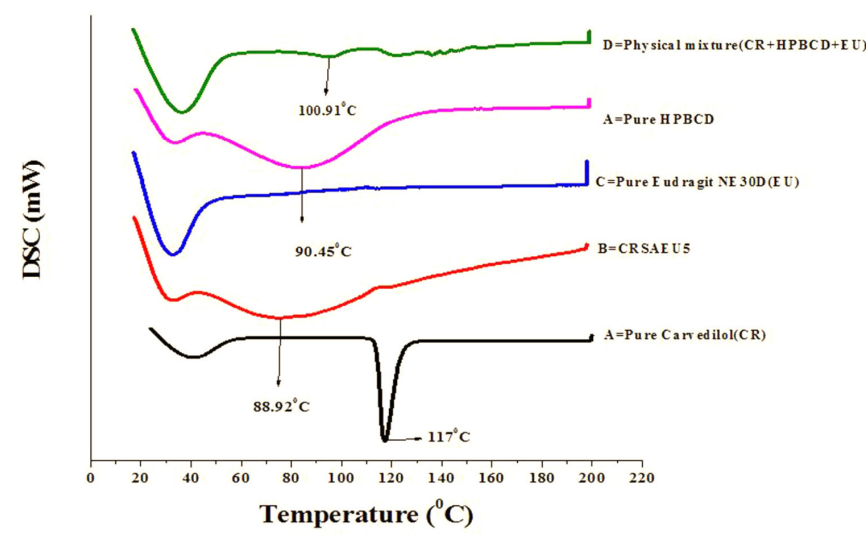

FIGURE 8 - DSC thermograms of CRSAEU5, pure carvedilol(CR), pure hydroxypropyl beta-cyclodextrin (HPBCD), physical mixture $(\mathrm{CR}+\mathrm{HPBCD}+\mathrm{EU})$ and pure Eudragit NE30D(EU). 


\section{Invivo animal studies}

The in vivo studies were carried out with the optimized formulation CRSAEU5 in Swiss albino mice to study the effect of microcapsules. For this purpose, the decrease in blood pressure was observed in hypertension induced mice (with diet mentioned in Table II), which were treated with CRSAEU5 formulation. The results were compared with group treated alone with pure drug CR and Control group. The effects were observed after $24 \mathrm{~h}$ from the day of treatment. The data of the blood pressure are presented in Figure 9.

From the Figure 9, it is clear that, the microcapsule formulation coded as CRSAEU5, was effective in decreasing the blood pressure as compared to pure drug group. This may be due to the increase in drug solubility in the body fluids by inclusion of complexing agent in the formulation.

The in vivo statistical ANOVA studies are shown in Figure 10, which shows that CRSAEU5 is most effective in controlling the hypertension in comparison to the pure drug. As the pure drug is lipophilic and very less bioavailable, but in the formulation the drug is complexed with HPBCD, thus the hydrophilicity of the drug is enhanced and thus it becomes more bioavailable.
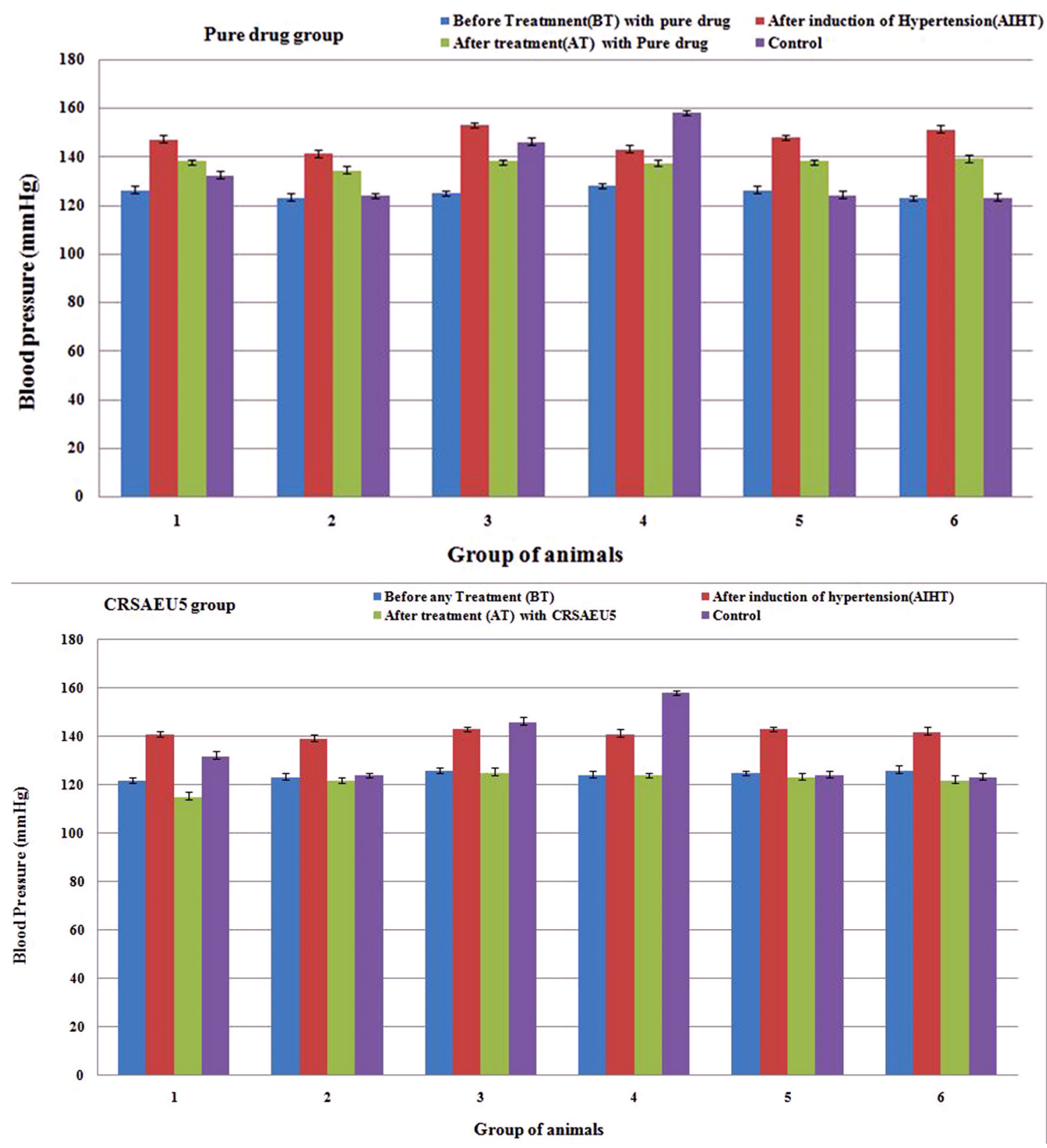

FIGURE 9 - In vivo studies of hypertension in mice. 

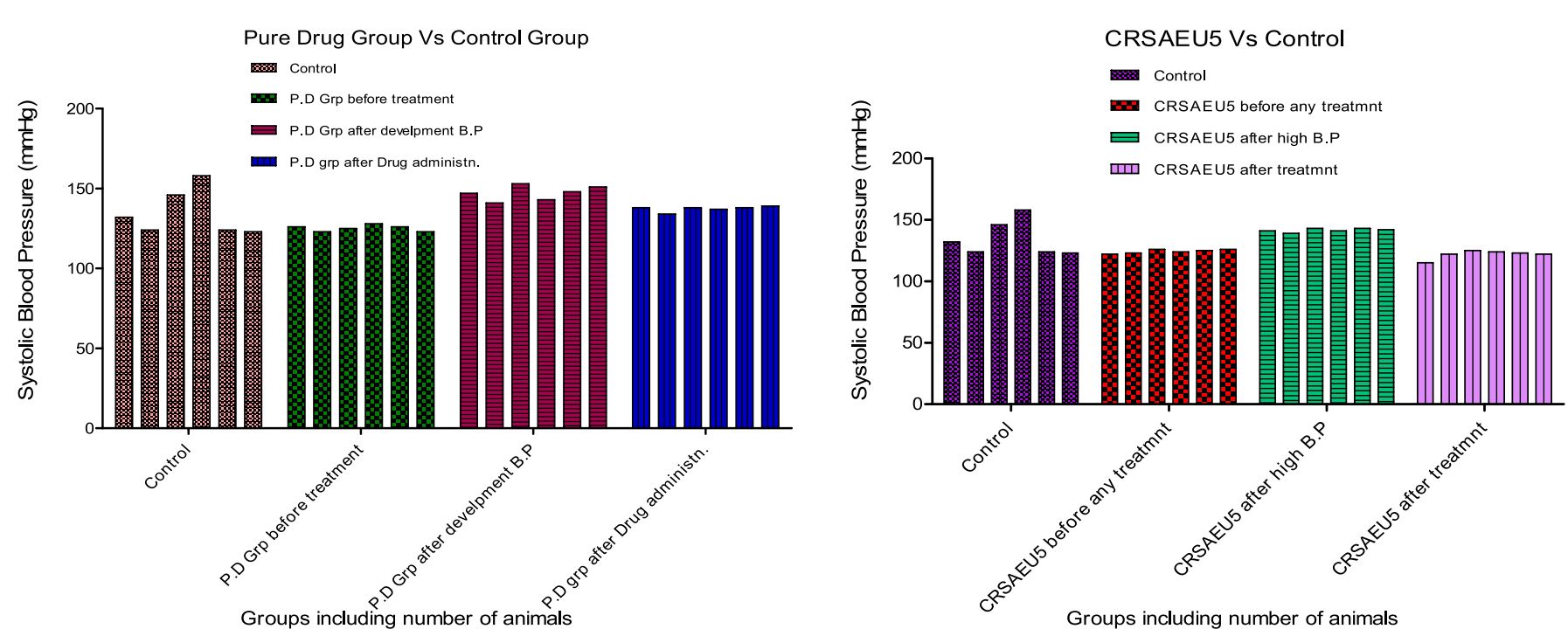

FIGURE 10 - Graphical representation of statistical ANOVA analysis of in vivo studies of optimized formulations of carvedilol, pure drug compared with control.

\section{CONCLUSIONS}

In this study, co-grinding technique has been applied to produce inclusion complex of CR with HPBCD and then incorporating this inclusion complex in the polymer matrix by using orifice gelation technique by use of a mixture of polymers Eudragit NE30D and sodium alginate which resulted in smooth, free flowing microcapsules having improved drug delivery. Higher drug loading efficiency was observed for all the formulations, and also the drug release was observed for a period of $13 \mathrm{~h}$. Thus the polymer Eudragit NE30D, showed promising result in retarding drug release. Moreover Eudragit NE30D did not show any incompatibility with neither the inclusion complex nor with the other polymer, i.e. with sodium alginate. Morphological analysis by Scanning Electron Microscopy showed that the formulations were almost spherical in shape and size. All the analytical studies showed that the drug and HPBCD had weak interactions leading to inclusion of drug carvedilol in the cyclodextrin cavity thereby improving the dissolution profile of the drug. The in vivo animal studies showed that the optimized formulation was effective in controlling the hypertension for a period of $24 \mathrm{~h}$.

\section{ACKNOWLEGDEMENTS}

Authors wish to thank Glenmark Pharmaceuticals,India, for providing Carvedilol as gift sample, thanks to Roquette, Lestrem,France for providing gift sample of Hydroxy propyl beta cyclodextrin, and also heartiest thanks to Evonik Degussa rohm Pharma, India, for providing gift sample of Eudragit NE 30D.Authors wish to thank CIF, BIT, Mesra, Ranchi for providing all the technical help in completing this study.

\section{List of Abbreviations}

CR:Carvedilol

HPBCD: Hydroxypropyl beta-cyclodextrin

EU: Eudragit NE30D

SA: sodium alginate

SEM: Scanning electron microscopy

FTIR: Fourier Transform Infrared Spectroscopy

XRD: X-ray diffraction

DSC: Differential scanning Calorimetry

Ci: Compressibility Index

\section{REFERENCES}

ARCHONTAKI, H.A.; VERTZONI, M.V.; ATHANASSIOU, M.M.H. Study on the inclusion complexes of bromazepam with beta and beta-hydroxypropyl cyclodexrin. J. Pharm. Biomed. Anal., v.28, n.3-4, p.761-769, 2002.

BAL, T.; MURTHY, N.P.; PANDEY, A. Evaluation of mucoadhesive carvedilol microcapsules prepared by orifice gelation technique. J. Pharm. Res., v.5, n.1, p.519-525, 2012.

BHUTANI, S.; HIREMATH, S.N.; SWAMY, P.V.; RAJU, S.A. Preparation and evaluation of inclusion complexes of carvedilol. J. Sci. Ind. Res., v.66, n.10, p.830-834, 2007. 
CARR, R.L. Evaluating flow properties of solid. Chem. Eng., v.72, n.3, p.163-168, 1965.

CHOWDARY, K.P.R.; RAO, S.Y. Design and in vitro evaluation of mucoadhesive microcapsules of glipizide for oral controlled release. A technical note. AAPS Pharm. Sci. Tech., v.4, n.39, p.1-6, 2003.

DEASY, P.B. Microencapsulation and related drug processes. United StatesNew York: Mercel Marcel Dekker, 1984. v.20, p.234-237.

DHAWAN, S.; SINGLA ,K.A.; SINHA, R.V. Evaluation of mucoadhesive properties of chitosan microspheres prepared by different methods. AAPS Pharm. Sci. Tech., v.5, n.4, p.1-7, 2004.

DHALIWAL, S.; JAIN, S.; SINGH, P.H.; TIWARY, A.K. Mucoadhesive microspheres for gastroretentive delivery of acyclovir: in vitro and in vivo evaluation. AAPS Pharm. Sci. Tech., v.10, n.2, p.322-330, 2008.

GUPTA, A.; GARG. S.; KHAR, K.R. Measurement of bioadhesive strength of mucoadhesive buccal tablets: design of an in vitro assembly. Indian Drugs, v.4, n.30, p.152-155, 1992.

HIGUCHI, T.; CONNORS, K.A. Phase solubility techniques. Adv. Anal. Chem. Instr., v.4, p.117-212, 1965.

HIRLEKAR, R.; KADAM, V. Preparation and characterization of inclusion complexes of carvedilol with methyl- $\beta$ cyclodextrin. J. Incl. Phenom. Macrocycl. Chem., v.63, n.3-4, p.219-224, 2009.

KUMAR, G.; GUPTA, G.A. Development and in vitro evaluation of osmotically controlled drug delivery system of carvedilol. Int. J. Pharm. Sci. Drug Res., v.1, n.2, p.8082, 2009.

MAgNUSDOTTIR, A.; MASSON, M.; LOFTSSON, T. Cyclodextrins. J. Incl. Phenom. Macroc. Chem., v.44, n.14, p.213-218, 2002.

MIRO, A.; QUAGLIA, F.; GIANNINI, L.; CAPPELLO, B.; ROTONDA, M.I.L. Drug/ cyclodextrin solid systems in the design of hydrophilic matrices: a strategy to modulate drug delivery rate. Curr. Drug. Deliv., v.3, n.4, p.373-378, 2006.
MUKHERJEE, B.; MAHAPATRA, S.; GUPTA, R.; TIWARI, A.; ARORA, P. A comparison between povidone-ethylcellulose and povidone-eudragit transdermal dexamethasone matrix patches based on in-vitro skin permeation. Eur. J. Pharm. Biopharm., v.59, n.3, p.475-483, 2005.

PATIL SANJAY, B.; SAWANT KRUTIKA, K. Development, optimization and in vitro evaluation of alginate mucoadhesive microspheres of carvedilol for nasal delivery. J. Microencapsul., v.26, n.5, p.432-443, 2009.

PATIL, D.A.; PATIL, G.B.; DESHMUKH, P.K.; BELGAMWAR, V.S.; FARSULE, R.A. Chitosan coated mucoadhesive multiparticulate drug delivery system for glicazide. Asian J. Pharm. Clin. Res.,v.2, n.2, p.62-67, 2009

PITHA, J.; MILECKI, J.; FALER, H.; PANNELL, L.; VEKAMA, K. Hydroxy propyl beta cyclodextrin: preparation and characterization; effects on the solubility of drugs. Int. J. Pharm., v.29, n.1, p.73-82, 1986.

QIANLI, Y.U.; DOUGLAS, F.L.; DENISE, S.; TAMARA, F.L.; JEFFREY, H.B.; RONALD, R.W. Characterization of high salt and high fat diets on cardiac and vascular function in mice. Cardiovasc. Toxicol., v.4, n.1, p.37-46, 2004.

RANJHA, N.M.; KHAN, H.; NAZEEM, S. Encapsulation and characterization of controlled release flubiprofen loaded microspheres using beeswax as an encapsulating agent. J. Mater. Sci. Mater. Med., v.21, n.5, p.1621-1630, 2010.

SALSA, T.; VEIGA, F.; PINA, M.E. Oral controlled release dosage forms. J. Cellulose ether polymers in hydrophilic matrices. Drug Dev. Ind. Pharm., v.23, n.9, p.929-938, 1997.

SCHAEFER, H.W.; POLITOWSKI, J.; HWANG, B.; DIXON JR., F.; GUTZAIT, L.G.A.; ANDERSON, K.; DEBROSSE, C.; BEAN, M.; RHODES ,R.G. Metabolism of Carvedilol in dogs, rats and mice. Drug Metab. Dispos., v.26, n.10, p.958-969, 1998.

SHEWALE, B.D.; SAPKAL, N.P.; RAVI, N.A.; GAIKWAD, N.J.; FURSULE, A. Effects of hydroxyl propyl beta cyclodextrin on the solubility of carvedilol. Indian J. Pharm. Sci., v.70, n.2, p.225-227, 2008.

SHARMA, H.K.; SARANGI, B.; PRADHAN, S.P. Preparation and in-vitro evaluation of mucoadhesive microbeads containing timolol maleate using mucoadhesive substances of Dillenia indica L. Arch. Pharm. Sci. Res., v.1, n.2, p.181$188,2009$. 
TANWAR, S.Y.; CHAUHAN, S.C.; SHARMA, A. Development and evaluation of carvedilol transdermal patches. Acta Pharm., v.57, n.3-4, p.151-159, 2007.

VYAS, A.; SARAF, S.; SARAF, S. Cyclodextrin based novel drug delivery systems. J. Incl. Phenom. Macrocycl. Chem., v.62, n.1-2, p.23-42, 2008.

WANG, Z.; DENG, Y.; SUN, S.; ZHANG, X. Preparation of hydrophobic drug cyclodextrin complexes by lyophilization monophase solution. Drug Dev. Ind. Pharm., v.32, n.1, p.73-78, 2006.
XIUDONG, L.; WEIMING, X.; QUN, L.; WEITING, Y.; YINGLI, F.; XIAOJUN, M.A.; QUAN, Y. Swelling behaviour of alginate-chitosan microcapsules prepared by external gelation or internal gelation technology. Carbohydr. Polym., v.56, n.4, p.459-464, 2004.

Received for publication on $03^{\text {rd }}$ September 2012 Accepted for publication on $21^{\text {st }}$ August 2013 